\title{
Understanding E-Democracy
}

Government-Led Initiatives for Democratic Reform

\author{
Julie Freeman*, Sharna Quirke** \\ *University of Canberra, Australia, Julie.Freeman@canberra.edu.au \\ ** Independent scholar, UK, sharna.quirke@gmail.com
}

\begin{abstract}
Information and communication technologies (ICTs) offer opportunities for greater civic participation in democratic reform. Government ICT use has, however, predominantly been associated with e-government applications that focus on one-way information provision and service delivery. This article distinguishes between e-government and processes of edemocracy, which facilitate active civic engagement through two-way, ongoing dialogue. It draws from participation initiatives undertaken in two case studies. The first highlights efforts to increase youth political engagement in the local government area of Milton Keynes in the United Kingdom. The second is Iceland's constitutional crowdsourcing, an initiative intended to increase civic input into constitutional reform. These examples illustrate that, in order to maintain legitimacy in the networked environment, a change in governmental culture is required to enable open and responsive e-democracy practices. When coupled with traditional participation methods, processes of e-democracy facilitate widespread opportunities for civic involvement and indicate that digital practices should not be separated from the everyday operations of government. While online democratic engagement is a slowly evolving process, initial steps are being undertaken by governments that enable e-participation to shape democratic reform.
\end{abstract}

Keywords: E-democracy, e-participation, e-government, democratic reform, local government youth engagement, Iceland constitution, information and communication technologies (ICTs)

P rospects of e-government have been idealised as heralding in a new era of democratic involvement, with opportunities for unmediated discussions, direct participation and representation, and greater transparency and accountability through political openness (see, for example, Coleman \& Blumler, 2009; Eggers, 2005; Wong \& Welch, 2004). It is argued, however, that governments have placed little emphasis on the development of online practices that enable civic contributions to impact decision-making, instead prioritising information dissemination and service delivery features (see, for example, O'Toole 2009; Jimenez, Mossberger \& Wu, 2012). Digital democracy, e-participation, and greater civic engagement have subsequently been labelled myths of e-government (Bekkers \& Homburg, 2007); unlikely to occur without broader changes in the culture of government to be more open, receptive and responsive to civic views (Cullen, 2006; Jensen, 2009).

The rapid influx of digital technologies has created immense opportunities for new forms of government-citizen communication. However, it should not be assumed that online government applications will transform democratic structures and practices as rapidly (see Seifert, 2006). According to Keane (2009), the current form of post-representative democracy has been in development for over 60 years, with this gradual shift the result of increased public involvement in political processes through the introduction of new communication technologies and practices. This article highlights that while e-democracy is a slower process than first anticipated, this does not undermine its capacity to facilitate democratic reform. Governments that recognise the technological impact on the paradigm shift in democracy are able to use information and communication technologies (ICTs) to address and adapt to increasing external pressures and broadening understandings of political representation and participation. 
This article explores e-participation efforts undertaken in the United Kingdom (UK) and Iceland to highlight how governments at varying levels are attempting to use ICTs to engage citizens in democratic practices. The UK case from the local government area of Milton Keynes is a targeted attempt to increase youth involvement in the democratic process. Iceland provides a nation-wide example of participatory democratic reform through its crowdsourced constitution initiative. These cases offer evidence of some of the ways that governments are combining ICT use with traditional political participation methods to actively facilitate civic engagement in democratic reform. Such developments are increasingly necessary for governments in order to maintain legitimacy in the networked environment by addressing altering notions surrounding political involvement. The success of e-participation initiatives depends, however, upon a change in governmental culture whereby representatives partially relinquish power and open political practices through more transparent operations, and offer receptive and responsive communication with citizens. The following section outlines the role of ICTs in democratic change, and discusses the distinctions between notions of e-government and e-democracy.

\section{Democratic Change and ICTs}

Changes to democratic processes have never been swift, but nor are they ever stagnant. Keane (2009) suggests that democracy is transforming to incorporate additional deliberative and participatory features, and the current post-representative democratic form has been in development since 1945. Under this form of 'monitory democracy', citizens are enfranchised through advanced technologies and communicative abundance. Power monitoring and controlling bodies, such as citizen assemblies, public inquiries and human rights organisations, help to ensure the accountability of governmental power throughout the entire social and political landscape. The importance of traditional democratic structures does not decline, but their pivotal position in politics is changing due to scrutiny and contestation from external influences (Keane, 2009). ICTs hold a vital position during these transformations. While civic ICT use can disrupt traditional forms of political power, governments are equally as able to deploy digital communications for their own political purposes (Hutchins \& Lester, 2011). For governments, ICT-enabled mechanisms offer opportunities to address and adapt to broadening understandings of political representation, transparency, participation and accountability. In turn, such practices offer citizens possibilities for additional involvement, understanding and engagement in the democratic system.

Information dissemination and service delivery often dominate government ICT use as these practices offer governments the greatest chance for economic gains (see, for example, O'Toole, 2009; Jimenez et al., 2012; Burgess \& Houghton, 2006). In large part, such developments have resulted from a governmental focus on improving efficiency through ICTs, rather than employing their use to aid the effectiveness of democratic processes (Verdegem \& Hauttekeete, 2010). Moreover, the prevalence of government centricity in e-government policies and practices neglects online civic inclusion in political decision-making (Verdegem \& Hauttekeete, 2010), with interactivity restricted in order for governments to maintain control of communication. Information dissemination and service delivery mechanisms provide little capacity for citizen involvement in government decisions, and civic participation undertaken offline remains more likely to impact the political system (Jensen, 2009). Opportunities for digital civic engagement in government decision-making have subsequently largely remained myths of e-government (Bekkers \& Homburg, 2007).

Despite the current approach undertaken by many governments, civic participation through ICTs has gained continuing and widespread attention, particularly due to its capacity to substantially contribute to democracy through greater engagement (see, for example, Hague \& Loader, 1999; Moon, 2002; Macintosh, 2004; Mossberger, Tolbert \& McNeal, 2008). Moreover, there is increasing recognition of the potential value that can be added through soliciting voluntary public input, or crowdsourcing, into political decision-making to enable collaborative democracy (see, for example, Brabham, 2008, 2009; Hilgers \& Ihl, 2010; Koch, Füller \& Brunswicker, 2011). For example, providing contexts for engagement and drawing upon civic insight can enable more informed government decision-making (see Aurigi, 2005; Couldry, Livingstone \& Markham, 2007). 
In Promise and Problems of E-Democracy, the Organisation for Economic Cooperation and Development (OECD, 2003) explores three joint perspectives on online engagement: information, consultation, and participation. 'Information' is a one-way relationship where governments produce and distribute information to citizens, such as occurs through websites and e-newsletters. This includes active attempts by governments to increase information dissemination on particular issues and arbitrary citizen access to information available through digital means upon demand. 'Consultation' involves a limited two-way process through which citizens can provide feedback to governments; for instance, via online surveys and petitions. This requires that citizens are provided with the information necessary to make informed decisions, but feedback is restricted to topics predetermined by governments, which means civic input has a limited capacity to shape political agendas and discourse. 'Participation' concerns the development of stronger relationships between citizens and governments, in which citizens are viewed as partners. It includes active involvement of citizens in the policy-making process and may take place through the use of, for example, digital discussions and wikis, where citizens can propose policy options and shape the direction of political dialogue. Governments, however, retain the responsibility for final decision-making and policy formation (OECD, 2003; see also OECD, 2001; Kingston, 2007).

It is this final form - participation - that empowers citizens to shape political agendas and alter the focus of government initiatives, enabling citizens to raise their views and suggest alternatives rather than being restricted to topics pre-set by governments. (Although it is worth noting that eparticipation builds upon the information and consultation opportunities offered through the other forms, so each offers a necessary component of digital citizen participation.) It is also this type of government-led online civic participation that offers governments the opportunity to address emerging external pressures, demands for greater involvement, and changing understandings and expectations related to democratic participation and representation. Given the above observation from the OECD (2003), it is necessary to draw a distinction between government use of ICTs to facilitate information, consultation and participation, and how these practices contribute to democracy. To do so, the following section explores the distinctions between e-government and edemocracy.

\subsection{What is E-Democracy?}

Democracy comes in many shapes and sizes (Keane, 2009) and so, arguably, the use of ICT in this context will also take various forms. As illustrated above, governments often adopt technological solutions for reasons of efficiency and cost savings, rather than to enhance democratic processes. It is therefore important that, rather than using concepts interchangeably, discussions of government ICT use draw a distinction between notions of e-government and edemocracy. In his empirical evaluation of e-government in the United States, Norris (2010) highlights that idealistic claims of e-government fostering democratic deliberation and increased civic participation and engagement have not been achieved. He distinguishes between egovernment, e-governance and e-democracy, and argues that while these three concepts are deeply intertwined, much academic literature contains the misconception that they are synonymous (Norris, 2010).

E-government, according to Norris (2010), is understood as electronic delivery of information and services, whereas e-governance relates more to regulation and control both by governments and citizens. In terms of e-democracy (and its various counterpart names, such as digital democracy and e-participation), Norris (2010) suggests that it involves providing citizens with access to government institutions and officials, and enabling civic participation through ICTs in matters of public concern (see also Bruns, 2012). In this vein, e-democracy can be understood as ongoing digital civic participation activities that partially disperse governmental power in order to enable the public to actively influence political decision-making (see Bruns, 2012; Norris, 2001; Freeman, 2013; Margolis \& Moreno-Riaño, 2009). 
In accepting the definitions of information, consultation and participation developed by the OECD (2001, 2003), and correlating these to the common terms and theories that have evolved in academic literature for more than a decade, it is possible to identify a clear distinction between egovernment and e-democracy. Figure 1 has been developed to illustrate this distinction. It demonstrates that the provision of information and services through e-government activities is only one aspect to digital civic engagement. Importantly, based on the fact that previous e-government initiatives have been mislabelled as e-democracy mechanisms (Norris, 2010), this distinction indicates that e-democracy may not be a myth; it just requires different methods of ICT-enabled democratic participation.

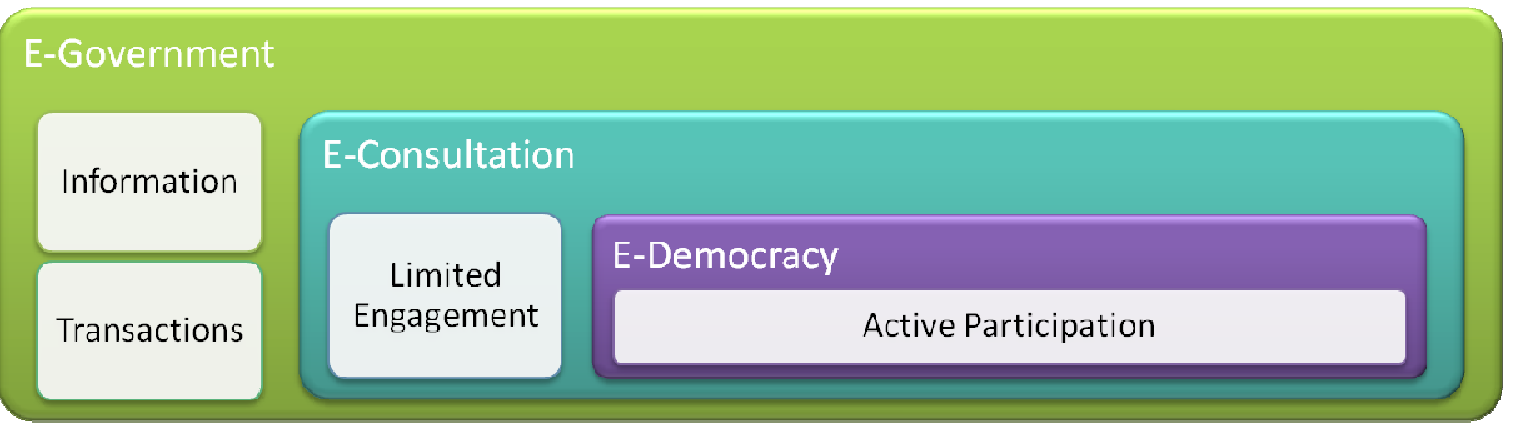

Figure 1: Forms of government-led e-engagement

As illustrated above, digital activities have specific aims and purposes, and therefore address different objectives and desired outcomes. Worth noting is that while both consultation and participation involve two-way communication between citizens and government, consultation initiatives seek civic feedback on discrete issues, whereas participation takes place through continuous dialogue. Each government activity is important and part of a meaningful process of democratic engagement. However, while they are intertwined (Norris, 2010), the different rationales highlight the importance of maintaining a clear distinction when examining government ICT use. Each form of engagement will utilise various ICTs in alternate ways. For example, e-democracy initiatives are ongoing activities that actively seek out the participation of citizens to shape political dialogue and intervene in policy-making. To do so, this requires information provision and civic feedback offered to governments, but this moves beyond the one-way dissemination of information associated with e-government activities and the restricted level of feedback that can be obtained through e-consultation.

As previously highlighted, improved efficiency of service delivery and increased civic access to information through e-government developments have been the predominant focus of government ICT use (see Freeman, 2013). These are important democratic developments as they facilitate civic equity towards public services and enable an informed citizenry. However, by themselves, these applications do not enable civic input into political agendas and policy processes, which would require greater two-way communication through e-participation. There have been significant academic contributions that have explored government ICT use to enhance citizen engagement in the policy process, which highlight how a gradual approach progresses from enabling to empowering communities through e-democracy (see, for example, Macintosh, 2004; Williamson, 2011; Chadwick, 2003).

It is important to note, however, that e-democracy practices can and do exist separately to government ICT use, which can be seen through, for example, citizen-led online political forums, the abundance of online news sources, and political exchanges through social media (see, for example, Chadwick \& May, 2003; Bruns, 2008; Kingston, 2007). While such practices may influence political agendas, they have a limited capacity to directly shape decision-making in comparison to government-led e-democracy efforts. Moreover, in order to maintain legitimacy and address the growing external pressures, contestation and scrutiny identified by Keane (2009), it is important for governments to offer spaces for democratic e-participation. 
ICT use has the greatest value for democratic reform when government provision of information, civic participation in policy-making, and regulatory transformations intersect. Here, technological advancements alter the functioning of power and authority through new citizenship practices (Smith, 2002; see also Henman, 2010). Effective governance subsequently involves dispersed power, with outcomes the result of a multiplicity of decisions from both vertical and horizontal relationships, rather than strategic decisions made by individual authorities (Ling, 2002). This is not to suggest an overhaul of current democratic structures to create direct forms of democracy, but that there is a need for additional deliberative opportunities for civic involvement in politics within the representative democratic model. Efforts towards more open government and enhanced civic engagement in political processes through e-democracy initiatives are being undertaken throughout the world. The following section outlines developments in the UK and Iceland to highlight how e-democracy is evolving.

\section{Government-Led E-Participation}

This section details two case studies of government-led e-participation to highlight the ways ICTs are used within broader democratic transformations. The first is a local government example from Milton Keynes in the UK where the aim was to increase youth participation and engagement with the political system. The second is Iceland's crowdsourced constitution, a nation-wide project used to gather civic input to directly shape constitutional reform. Details of these cases were primarily obtained through analysis of government documents, websites, and surrounding political commentary. In the case of Milton Keynes, additional information relating to funding and the developmental approach undertaken by the council and its youth workers was provided directly by the local government.

These case studies have been selected for examination as they highlight that governments at various levels are developing e-participation practices to facilitate democratic change. In both instances, e-participation is used to support and supplement broader offline civic engagement in democratic reform. By taking this approach, these examples demonstrate the importance of integrating e-participation into governments' everyday practices, rather than viewing it as separate to the operations of government. Whether targeted e-participation initiatives aimed at a particular group of constituents or nation-wide mechanisms for engagement, these cases demonstrate that the success of e-democracy processes is inextricably linked to the ways that civic involvement is considered in broader political processes; that is, whether governments are open to empowering citizens by incorporating their views in decision-making.

\subsection{Local E-Participation: Milton Keynes and Youth Engagement}

Local initiatives offer useful contexts for e-participation (Freeman, 2013). It is at this level where the bulk of civic involvement in government takes place (Shackleton, 2010), particularly due to increased interest in issues of direct relevance and familiarity to citizens (Margolis \& Moreno-Riaño, 2009; Couldry \& Langer, 2005). The UK local government of Milton Keynes offers an example of ICT use to facilitate increased local participation in democratic practices.

According to 2011 census data, Milton Keynes has a particularly young population, with 22.3 percent of its approximately 250,000 residents under 16 years of age. By way of comparison, this figure is 18.9 percent across England as a whole (Milton Keynes Council, 2012). With its young demographic, the objective for the local government was to increase youth involvement in the democratic process. Until this time, it was common practice for outreach work in youth engagement to be primarily conducted through physical forums such as youth centres and schools. This social contact was built on the premise that positive engagement with a youth worker may lead to wider life aspirations. However, youth centre engagement was decreasing and, with less young people at centres or out on the streets, the traditional practices of outreach work became increasingly challenging. In other words, Milton Keynes was faced with a withdrawal from public life and a potential increase in political apathy amongst its youth (see Sennett, 1977). 
Milton Keynes received funding in the amount of $£ 37,000$ from the National Youth Agency to specifically address youth opportunities. Some within the council recognised that the online world may have influenced the reduced physical presence at traditional engagement forums, and the initial reaction saw technology as a hindrance to engagement, rather than as a potential facilitator. There was a strong school of thought within the council that it was youth workers who were failing to connect with young people, with scarce physical attendance at centres viewed as the result of poor outreach work. However, the youth workers identified the council's antiquated attitude to the relationship between engagement and technology. After receiving funding, Milton Keynes teamed with a small business, which specialises in using emerging technologies as tools to engage and inspire, to explore the use of technology to increase youth participation, including what form this type of participation may take. The end goal remained the same: to develop positive engagement and increase life aspirations; but the forums and how to achieve this were changing.

The first approach to increase engagement was to use Facebook and Twitter to share information, initially one-way, on behalf of the Milton Keynes Council. The aim was to connect with traditionally 'hard to reach' groups such as disabled, lesbian, gay, bisexual, transgender and hidden communities. The approach created differing reactions across the council, as using social media in a purposeful and targeted way was perceived by some as predatory and inappropriate, rather than being seen as a new form of outreach. Such cultural resistance is a common trait amongst governments that are reluctant to utilise social media in their communicative practices (see, for example, Jensen, 2009; Chadwick, 2011; Millham \& Eid, 2009).

The project made a shift towards more receptive and responsive e-participation by using the same social networking technologies to seek feedback from young people, using open questions and monitoring the responses. This move was a particularly important feature to enable increased engagement, as social media use that is restricted by only allowing youth to like, share or follow issues does little to encourage advanced forms of participation (Macnamara, 2012). Young people in Milton Keynes wanted greater transparency and involvement in the decisions made on youth related issues, particularly transport and employment opportunities in the local area. They identified that the best way to take their concerns forward was via a single point of common contact within the structure of the council, combined with ongoing social media dialogue.

In a rare move, the council partially relinquished control of its own website, allowing a page to be re-branded, 'My Say MK' (see http://www.milton-keynes.gov.uk/positiveactivities/), and the content to be managed by youth volunteers. Young people were provided with the power to engage and collaborate with others on issues of common concern within the auspice of the council website. Within a few months, the webpage was enabling dialogue and discussion between young people, which was supported by the council youth workers. Several engagement events were held (addressing traditional youth work objectives) and a number of initiatives were taken forward in response to concerns raised by youth around local transport.

Alongside the success of the My Say MK venture, an MK Youth Cabinet was established in 2009. Young people self nominated as candidates with a short two-paragraph manifesto and campaign on local priorities conducted both online and in person. Originally for ages 11-16, but later expanded to 11-19 years, over 2,500 youth e-voted via the My Say MK website in the first election. This represented ten percent of Milton Keynes' youth population at the time (Milton Keynes Council, 2009). In the most recent election, more than 40 young people stood as candidates for the 25 cabinet positions, and 7,393 voted (Milton Keynes Council, 2011). These figures indicate the initiative's success in facilitating both ongoing and increasing levels of youth engagement. The MK Youth Cabinet now meets monthly and is provided a (small) budget from the council to self-manage. Every three months, they meet with the adult cabinet and present their issues. The adult cabinet agrees upon actions to be taken and responds with updates in the following quarter.

This example from Milton Keynes offers evidence of the ways that ICT use facilitates increased levels of political engagement. Moreover, in its attempt to counteract declining public life and increasing political apathy amongst youth, these developments have both led to greater political 
participation in democratic processes and helped to educate youth on the operations of political systems, such as election campaigning and cabinet meetings. Such localised initiatives provide practical settings for democratic engagement, particularly as ICT use at higher levels of government creates problems associated with scale and manageability (Jimenez et al., 2012). Despite such challenges, ICTs can be useful to facilitate broader democratic transformations. The following section outlines ICT use in Iceland's constitutional reform process. Iceland is a small country in terms of population (with approximately 320,000 residents), so it does not face the same scale and manageability issues as larger nations. However, it offers a useful example of the way that citizens can contribute to national policy discourse and offers a general e-democracy framework that other countries may follow.

\subsection{National E-Participation: Iceland's Constitutional Crowdsourcing}

Founded in $930 \mathrm{AD}$, Iceland's Parliament, Althingi, is one of the oldest parliamentary institutions in the world. Iceland's existing constitution came into force when it gained independence from Denmark in 1944 and, at that time, Iceland used Denmark's constitution as a basis for its own. In 2009, in the midst of the global financial crisis, Iceland's banking sector collapsed, which led to extensive civil protests and political instability with calls for constitutional reform. The government was forced to resign over its handling of the economic challenges and a new government was formed, which addressed the constitutional reform issue.

The government turned to the public and invited nearly 1,000 citizens randomly selected from the national voting registry to attend a national forum to brainstorm ideas for constitutional reform (Stjórnlagaráo, 2011). In 2010, following a conclusion reached in the forum, 25 independent citizens were elected by the public to form a Constitutional Council. They were tasked with drafting a new constitution for the country, which in turn was to be presented to the public through a referendum and then to Althingi for final approval. The council, which consisted of delegates of diverse backgrounds including university professors, farmers, lawyers, and media professionals, undertook a unique approach where end-to-end citizen participation was encouraged during the drafting of the Bill. The main themes that the council observed during its work were distribution of power, transparency and responsibility (Stjórnlagaráo, 2011) and, in this regard, actively sought to increase public participation in the drafting process. Notably, the council used social media and crowdsourcing techniques.

Iceland is well positioned to utilise e-democracy practices as it has one of the highest household Internet penetration rates (at 95 percent in 2012) in the world (Statistics Iceland, 2012). Until recently, however, Iceland had received a relatively low ranking in relation to its participatory egovernment development. In 2010, the United Nations' e-participation index ranked Iceland at 135. A rapid increase in online engagement initiatives saw this placing jump to number 26 in 2012 (see United Nations, 2010, 2012).

Through the use of ICTs, particularly social media, the council approached the general population to offer their ideas as to what the new constitution should contain. Signalling a shift in the open and participatory nature of representative government, the consultation offered responsive and ongoing opportunities for involvement between citizens and the council, and between citizens. Every week for approximately four months, the council posted a draft clause on its website (see http://stjornlagarad.is/starfid/). Citizens could comment on the website, join discussions on the council's Facebook page and Twitter profile, or submit their views via written letter. Members of the Constitutional Council posted videos on YouTube and used Flickr to show photos of the council at work. Council meetings were open to the public and streamed live via the website and Facebook page.

The traditional letter method was the most commonly used form of public participation during the constitutional reform process, with a total of 3,600 responses in contrast to the 370 comments posted on the council's website (Stjórnlagaráo, 2011). The previously limited digital participation opportunities available in Iceland likely contributed to the dominance of this traditional form of 
political involvement. Additionally, the preference for written letters may also be due to the fact that they allow a more comprehensive message to be developed compared to the nature of online communications, which is often restricted to shorter word limit contributions. These observations highlight the importance of combining traditional and online forms of participation to encourage active involvement in democratic reform, and to ensure equity of civic connection with government for those with limited ICT access and skills (see, for example, Beynon-Davies \& Martin, 2004; Lowndes, Pratchett \& Stoker, 2001; Tambini, 1999).

There were political parties and special interest groups that were opposed to constitutional reform (see Gylfason, 2013). As all members of the Icelandic community were invited to participate through the council's initiatives, special interest groups and lobbyist had the same opportunities to be involved as individuals. Previously, the direct involvement of such groups in democratic processes had been undertaken through invitations to legislative meetings and use of particular platforms for individual organisations. Interestingly, without specifically targeted opportunities for organised groups' involvement, their representatives did not respond to the council's open invitation to the public to provide feedback on the draft constitution (Gylfason, 2013).

The Constitutional Council delivered the Bill to parliament in July 2011 and then disbanded. The Bill was bought to a national referendum in late 2012. Just under 50 percent of the voting population participated, with 64.2 percent voting in favour of a new constitution based on the crowdsourced version (Kosningavefur Innanríkisráđuneytisins, 2012). However, this result was not binding as Althingi retained responsibility for the final decision to pass the new constitution. Some opposing political parties proposed further amendments to the document and raised the threshold of votes needed to approve constitutional changes, both in Althingi and amongst the public (Gylfason, 2013). Althingi was also soon to be dissolved in preparation for a general election in late April 2013. Political parties opposed to the constitutional reform successfully applied pressure to secure the deferment of voting on the Bill until after the general election (Gylfason, 2013), meaning the new government would determine when, if at all, the vote by Althingi would be held. To date, the new government elected in 2013 has yet to raise the matter of constitutional reform.

Public involvement in Iceland's constitutional reform took place from beginning to end - from the initial ideas and discussion, to the development and drafting of the Bill, to voting in its referendum. Despite the referendum outcome and the levels of participation underpinned by the use of ICTs, the Icelandic constitutional reform remains unresolved. Moreover, opportunities for further civic participation in the reform process have not, at this time, been offered. This presents a potentially problematic situation for Iceland as the e-participation opportunities offered have been focused around an individual acute event (Bruns, 2012). In contrast, e-democracy should continuously unfold and develop over time. Given the Icelandic civil unrest that created the need for more open government-citizen dialogue and the efforts undertaken by members of the public in formulating the draft constitution, preventing ongoing civic involvement on the matter risks further civil revolts.

Nonetheless, the Icelandic case signals that governments are beginning to recognise the need to address external threats, perceived or otherwise, on parliamentary and elected representation through more open forms of government, with greater emphasis placed on public involvement through the use of ICTs. While the reform is still unresolved, the Icelandic constitutional process was innovative. It nods towards a more transparent relationship between citizens and governments that recognises the potential for citizens to be empowered at the centre of political debate, rather than be spectators. Iceland therefore offers a useful example of the way that government-led online participation practices can be employed in order to address changing democratic understandings and expectations. In this instance, power was dispersed to the public, including the Constitutional Council. However, the decision ultimately remains with Althingi. The following section outlines the importance of the types of initiatives undertaken in Iceland and Milton Keynes for changing democratic processes. 


\section{Using ICTs in Democratic Reform}

In the past and still today, e-government techniques include limited consultation exercises seeking reactions and views from citizens to governments through controlled initiatives. These often occur in closed forums, such as emails to a generic inbox set up specifically for the consultation and seeking responses to pre-set questionnaires. In contrast, government-led edemocracy is less controlled, with ongoing discourse and greater transparency that opens political processes to the public. E-democracy should not be considered as a list of discreet activities conducted online between an individual and the government, but as continuous engagement between multiple individuals and their government through open and transparent platforms (see Bruns, 2012). In this regard, the Milton Keynes and Icelandic case studies support Norris' (2010) empirical survey-based evidence that e-government does not naturally lead to e-democracy; whilst they are interrelated, they are not synonymous (Norris, 2010).

The case studies presented here illustrate that the scope of government ICT use has advanced from its original focus on one-way information dissemination and service delivery to incorporate eparticipation by actively seeking civic views to inform broader democratic processes. One noticeable common characteristic in both of these cases is that of continuous, triangular engagement, using qualitative dialogue to achieve specific aims and objectives. Engagement should not be based upon one-way, transactional activities such as a series of online surveys, petitions or voting, which are often ill-described as e-participation activities (Norris, 2010). Rather, engagement consists of ongoing dialogue both bilaterally between citizens and governments, and more broadly amongst various citizens with integrated feedback offered to governments, moving towards a triangular approach. In this way, citizens' awareness of other perspectives helps to foster debate and increase understanding, and also improves the transparency of political issues and processes throughout society.

Opening such channels of communication online to aid transparency requires governments to partially relinquish control of communications, which empowers citizens to further scrutinise political processes. This may be a daunting thought for politicians who fear losing control of political messages. It is difficult to predict the possible outcomes and consequences arising from the increased visibility of previously hidden political practices, which may lead to volatile sites of resistance (see Thompson, 2005; Lester \& Hutchins, 2012). Further challenges also arise from this situation in terms of who maintains accountability for the decisions that are made (see Wong \& Welch, 2004; Curry, 2001). In the cases presented here, the governments ultimately retain decision-making power while drawing from civic input. Governments may be reluctant to incorporate civic views into decision-making if it is the governments that bear the burden of responsibility for decisions that may be unsuccessful.

Conversely, potential benefits from transparent e-participation practices include, for example, increasing government legitimacy (see Fountain, 2001; Homburg, 2008), added value to decisionmaking (see Brabham, 2008, 2009; Hilgers \& Ihl, 2010), and improving civic satisfaction and trust with political processes (see West, 2005; Tolbert \& Mossberger, 2006). Such benefits cannot be achieved without governments trialling new forms of democratic involvement. In both of these case studies, the governments' previous communications surrounding political issues were not resonating with citizens. The actions taken were therefore necessary to maintain governmental legitimacy by increasing the transparency of their operations and enabling continuous dialogue with citizens (see Cohen, van Geenhuizen \& Nijkamp, 2005). The success of opening representation and enabling ongoing dialogue depends, however, upon a culture change within governments to be more amenable to civic input and prepared to relinquish a degree of control over communication practices (see Hernon \& Cullen, 2006; Flamm, Chaudhuri \& Associates, 2006).

Both Milton Keynes and Iceland highlight that a government culture change to facilitate edemocracy processes can take place (see Cullen, 2006). Such a change requires governments to become more responsive and receptive to civic views (see Jensen, 2009; Gauld, Gray \& McComb, 2009). Milton Keynes has developed an ongoing process that reflects the growing need to gather 
civic input on issues that affect the community, and which helps to counteract declining public interest and political apathy. The Icelandic case provides evidence that external pressures are creating the need for change in the open nature of government. Iceland had just gone through a period of economic and political upheaval, with civil protests and claims made that the government's lack of transparency contributed to the depth of the problem. This series of events meant the government needed to re-emphasise its legitimacy. To do so, the government accepted and engaged with a process of e-democracy to further empower citizens through greater transparency and involvement in political decision-making. This situation illustrates a key point: If the economic and political upheaval had not taken place, then it is possible that engagement in, and acceptance of, the e-democracy process may not have been undertaken or as welcomed.

This observation highlights a fundamental difference between the case studies. Milton Keynes sought to counter decreasing levels of political engagement through an ongoing effort to enable youth to both develop an interest in politics and contribute their opinions to decision-making. In Iceland, by way of contrast, external civil action placed pressure on the government to adapt its practices and redistribute power, leading the government to implement mechanisms for citizen participation. In such cases, if governments fail to address growing levels of scrutiny, then they risk provoking further contestation from the electorate. The key difference between these cases is that Milton Keynes was proactive in its approach to increasing ongoing civic engagement, whereas the developments undertaken in Iceland were reactive temporary attempts to address civil demands. In the context of monitory democracy (Keane, 2009), proactive provision of e-participation opportunities as occurred in Milton Keynes may help to prevent future civil unrest. This suggests that, to prevent similar predicaments as those that took place in Iceland, other governments may need to take a more pre-emptive approach to change their governmental culture, open representation, and enable additional opportunities for democratic civic involvement.

Both of these case studies also highlight the importance of combining both on and offline methods of political participation in order to encourage greater democratic engagement (see Beynon-Davies \& Martin, 2004; Lowndes et al., 2001). The reasons for this are two-fold. On the one hand, using both traditional and online methods of participation enables wider engagement by ensuring equity of civic involvement with government. On the other hand, democratic reform is not something that can take place entirely through the online realm. Online communications practices offer mechanisms to supplement and support broader democratic transformations in the governance structures and processes that resonate through all aspects of everyday life. Edemocracy therefore should not be thought of as separate to everyday processes of government, but as a way to achieve governmental aims. Use of ICTs for democratic reform does not require governments to completely diverge from traditional understandings of political processes, but to adapt the political mindset in order to recognise that new mechanisms can support traditional objectives. While digital technologies are playing a key role in democratic reform, the impact of ICT use is ultimately reliant upon the willingness and capacity of governments to incorporate civic views in decision-making.

\section{Conclusion}

Democratic change is a gradual process and the adoption of ICTs by governments is no different (see Seifert, 2006). Use of ICTs to facilitate democratic practices does, however, offer opportunities to take the next step in broader democratic reform to shape the future of democracy. For this reason, e-democracy and the implications that stem from the observations presented in this article are important for governments to understand in order to advance current practices. While advancements may come slowly, once the decision is made to implement participatory practices, e-democracy processes can be achieved reasonably quickly. The cases presented here highlight that, in order to address increasing scrutiny and external pressures to maintain legitimacy, governments are beginning to develop transparent e-participation practices. These initiatives offer citizens spaces for engagement through ongoing dialogue and a greater degree of power in decision-making processes. The success of current mechanisms is, however, limited through 
government retention of the responsibility for final decision-making; the likely result of concerns surrounding accountability and the potential negative ramifications of poor decisions for government legitimacy. Despite these limitations, these case studies illustrate that governments are taking the initiative to enable citizen input to inform decision-making, which is an important step for democratic reform.

E-democracy is a means, not an end, to democratic reform. The evidence presented here from Milton Keynes and Iceland demonstrates that e-democracy should be understood as a process of continuous dialogue that facilitates ongoing civic engagement, rather than a series of discreet or static activities facilitated by technology (see Coleman \& Blumler, 2009). Moreover, e-participation needs to be coupled with offline participation methods. This enables broad opportunities for civic engagement, and may help governments recognise that such practices are not separate to the everyday operations of government; they simply offer an additional means to supplement and support democratic processes. Such developments may enable governments to maintain their legitimacy in the networked environment, but this will require a change in organisational culture to address increasing pressures, both external and internal, and to be more receptive and responsive towards civic views. The outcome of culture change, combined with the transparent and interactive nature of many social media techniques, is likely to lead to a power shift between citizens and their elected decision-makers, which requires politicians and institutions to relinquish a degree of their own power. This is a likely cause of existing government reluctance to implement opportunities for e-participation, with the focus instead often remaining on e-government practices.

To date, the emphasis on government centricity in government ICT use remains pervasive. Greater focus needs to be given, by governments and researchers alike, on the potential for citizen-centric practices to contribute to democratic reform. Chadwick and May (2003) highlight that a participatory model of e-government recognises a more horizontal process whereby public activities through non-government websites contribute to civil society. At this time, it would be a substantial leap forward for governments to directly consider such citizen-led communications in decision-making processes. But such activities are being used by citizens as tools to pressure governments to undertake change. Further research into the types of initiatives developed both by and for citizens may therefore reveal insight into the civic pressures that demand e-democracy, and assist governments in planning for the future. The examples of Iceland and Milton Keynes highlight that a change of culture towards e-democracy is possible, with citizens and communities beginning to set political agendas within government-led initiatives. A gradual democratic shift through eparticipation has begun.

\section{References}

Aurigi, (2005). Making the Digital City: The Early Shaping of Urban Internet Space. Aldershot, Hampshire: Ashgate Publishing Limited.

Bekkers, V., \& Homburg, V. (2007). The myths of e-government: Looking beyond the assumption of a new and better government. The Information Society: An International Journal, 23(5), 373-382.

Beynon-Davies, P., \& Martin, S. (2004). Electronic local government and the modernisation agenda: Progress and prospects for public service improvement. Local Government Studies, 30(2), 214-229.

Brabham, D. C. (2009). Crowdsourcing the public participation process for planning projects. Planning Theory, 8(3), 242262.

Brabham, D. C. (2008). Crowdsourcing as a model for problem solving: An introduction and cases. Convergence: The International Journal of Research into New Media Technologies, 14(1), 75-90.

Bruns, A. (2012). Towards distributed citizen participation: Lessons from Wikileaks and the Queensland floods. eJournal of eDemocracy and Open Government, 4(2), 142-159.

Bruns, A. (2008). Blogs, Wikipedia, Second Life, and Beyond: From Production to Produsage. New York: Peter Lang Publishing, Inc. 
Burgess, S., \& Houghton, J. (2006). E-government in Australia. In P. Hernon, R. Culleen \& H. C. Relyea (Eds.), Comparative Perspectives on E-Government: Serving Today and Building for Tomorrow (pp. 84-101). Lanham, Maryland: Scarecrow Press, Inc.

Chadwick, A. (2011). Explaining the failure of an online citizen engagement initiative: The role of internal institutional variables. Journal of Information Technology \& Politics, 8(1), 21-40.

Chadwick, A. (2003). Bring e-democracy back in: Why it matters for future research on e-governance. Social Science Computer Review, 21(4), 443-455.

Chadwick, A., \& May, C. (2003). Interaction between states and citizens in the age of the Internet: 'E-government' in the United States, Britain, and the European Union. Governance: An International Journal of Policy, Administration, and Institutions, 16(2), 271-300.

Cohen, G., van Geenhuizen, M., \& Nijkamp, P. (2005). ICT as a contributing factor to urban sustainable development: Policymaking in Dutch cities. In M. van Geenhuizen, D. V. Gibson \& M. V. Heitor (Eds.), Regional Development and Conditions for Innovation in the Network Society (pp. 99-117). West Lafayette, Indiana: Purdue University Press.

Coleman, S., \& Blumler, J. G. (2009). The Internet and Democratic Citizenship: Theory, Practice and Policy. New York: Cambridge University Press.

Couldry, N., \& Langer, A. I. (2005). Media consumption and public connection: Towards a typology of the dispersed citizen. The Communication Review, 8(2), 237-257.

Couldry, N., Livingstone, S., \& Markham, T. (2007). Media Consumption and Public Engagement: Beyond the Presumption of Attention. Basingstoke, Hampshire: Palgrave Macmillan.

Cullen, R. (2006). E-Government and the Digital Divide. In P. Hernon, R. Cullen \& H. C. Relyea (Eds.), Comparative Perspectives on E-Government: Serving Today and Building for Tomorrow (pp. 289-313). Lanham, Maryland: Scarecrow Press Inc.

Curry, N. (2001). Community participation and rural policy: Representativeness in the development of millennium greens. Journal of Environmental Planning and Management, 44(4), 561-576.

Eggers, W. D. (2005). Government 2.0: Using Technology to Improve Education, Cut Red Tape, Reduce Gridlock, and Enhance Democracy. Lanham, Maryland: Rowman \& Littlefield Publishers, Inc.

Flamm, K., Chaudhuri, A., \& Associates, (2006). The internet, the government, and e-governance. In P. Hernon, R. Cullen \& H. C. Relyea (Eds.), Comparative Perspectives on E-Government: Serving Today and Building for Tomorrow (pp. 331-348). Lanham, Maryland: Scarecrow Press Inc.

Fountain, J. E. (2001). Building the Virtual State: Information Technology and Institutional Change. Washington: Brookings Institutional Press.

Freeman, J. (2013). Local e-government and citizen participation: Case studies from Australia and Italy. In J. R. Gil-Garcia (Ed.), E-Government Success Around the World: Cases, Empirical Studies, and Practical Recommendations (pp. 235-258). Hershey, Pennsylvania: IGI Global.

Gauld, R., Gray, A., \& McComb, S. (2009). How responsive is e-government? Evidence from Australia and New Zealand. Government Information Quarterly, 26(1), 69-74.

Gylfason, T. (2013). Democracy on ice: A post-mortem of the Icelandic constitution. OpenDemocracy: Free thinking for the world, 19 June. Retrieved September 26, 2013, from http://www.opendemocracy.net/can-europe-make-it/thorvaldurgylfason/democracy-on-ice-post-mortem-of-icelandic-constitution

Hague, B. N., \& Loader, B. D. (Eds.) (1999). Digital Democracy: Discourse and Decision Making in the Information Age. London: Routledge.

Henman, P. (2010). Governing Electronically: E-Government and the Reconfiguration of Public Administration, Policy and Power. Basingstoke, Hampshire: Palgrave Macmillan.

Hernon, P., \& Cullen, R. (2006). E-government: Transforming government. In P. Hernon, R. Cullen \& H. C. Relyea (Eds.), Comparative Perspectives on E-Government: Serving Today and Building for Tomorrow (pp. 3-21). Lanham, Maryland: Scarecrow Press Inc.

Hilgers, D., \& Ihl, C. (2010). Citizensourcing: Applying the concept of open innovation to the public sector. The International Journal of Public Participation, 4(1), 67-88.

Homburg, V. (2008). Understanding E-Government: Information Systems in Public Administration. New York: Routledge.

Hutchins, B., \& Lester, L. (2011). Politics, power and online protest in an age of environmental conflict. In S. Cottle \& L. Lester (Eds.), Transnational Protests and the Media (pp. 159-171). New York: Peter Lang.

Jensen, M. J. (2009). Electronic democracy and citizen influence in government. In C. G. Reddick (Ed.), Handbook of Research on Strategies for Local E-Government Adoption and Implementation: Comparative Studies (pp. 288-305). Hershey, Pennsylvania: IGI Global. 
Jimenez, B. S., Mossberger, K., \& Wu, Y. (2012). Municipal Government and the Interactive Web: Trends and Issues for Civic Engagement. In A. Manoharan \& M. Holzer (Eds.), E-Governance and Civic Engagement: Factors and Determinants of E-Democracy (pp. 251-271). Hershey, Pennsylvania: IGI Global.

Keane, J. (2009). The Life and Death of Democracy. London: Simon \& Schuster UK Ltd.

Kingston, R. (2007). Public participation in local policy decision-making: The role of web-based mapping. The Cartographic Journal, 33(2), 138-144.

Koch, G., Füller, J., \& Brunswicker, S. (2011). Online crowdsourcing in the public sector: How to design open government platforms. In A. A. Ozok \& P. Zaphiris (Eds.), Online Communities and Social Computing (pp. 203-212). Berlin: Springer.

Kosningavefur Innanríkisráđuneytisins. (2012). Outcome of the Counting of the Votes Cast in the Referendum on 20 October 2012. Retrieved January 30, 2013, from http://www.kosning.is/thjodaratkvaedagreidslur2012/english/nr/7991

Lester, L., \& Hutchins, B. (2012). The power of the unseen: Environmental conflict, the media and invisibility. Media, Culture \& Society, 34(7), 847-863.

Ling, T. (2002). Delivering joined-up government in the UK: Dimensions, issues and problems. Public Administration, 8(4), 615-642.

Lowndes, V., Pratchett, L., \& Stoker, G. (2001). Trends in public participation: Part 2 - citizens' perspectives. Public Administration, 79(2), 445-455.

Macintosh, A. (2004). Characterizing e-participation in policy-making. In Proceedings of the $37^{\text {th }}$ Hawaii International Conference on System Science (HICSS'04) (pp. 50117-50126). Washington: Computer Society Press.

Macnamara, J. (2012). Democracy 2.0: Can social media engage youth and disengaged citizens in the public sphere? Australian Journal of Communication, 39(3), 65-86.

Margolis, M., \& Moreno-Riaño, G. (2009). The Prospect of Internet Democracy. Farnham, Surrey: Ashgate Publishing Limited.

Millham, R., \& Eid, C. (2009). Digital cities: Nassau and Bologna - A study in contrasts. In Proceedings of the IEEE LatinAmerican Conference on Communications, IEEE Communications Society (pp. 1-6). Medllin, Colombia: LATINCOM. Retrieved January 20, 2013, from http://ieeexplore.ieee.org/xpls/abs all.jsp?arnumber $=5305144$

Milton Keynes Council. (2012). Milton Keynes 2011 Census Headlines. Retrieved January 25, 2013, from http://www.mkiobservatory.org.uk/document.aspx?id=10185\&sitelD $=1026$

Milton Keynes Council. (2011). Youth Cabinet Report: March to May 2011. Retrieved January 25, 2013, from http://www.milton-keynes.gov.uk/positiveactivities/displayarticle.asp?ID=65261

Milton Keynes Council. (2009). Youth Cabinet Report: March, April \& May 2009. Retrieved January 25, 2013, from http://www.milton-keynes.gov.uk/positiveactivities/displayarticle.asp?ID=65261

Moon, M. J. (2002). The evolution of e-government among municipalities: Rhetoric or reality? Public Administration Review, 62(4), 424-433.

Mossberger, K., Tolbert, C. J., \& McNeal, R. S. (2008). Digital Citizenship: The Internet, Society, and Participation. Cambridge, Massachusetts: The MIT Press.

My Say MK. (2012) My Say MK by MK Council (website). Retrieved January 25, 2013, from http://www.miltonkeynes.gov.uk/positiveactivities/

Norris, D. F. (2010). E-government... not e-governance... not e-democracy: Not now! Not ever? In J. Davies \& T. Janowski (Eds.), Proceedings of the $4^{\text {th }}$ International Conference on Theory and Practice of Electronic Governance (ICEGOV'10) (pp. 339-346). New York: ACM.

Norris, P. (2001). Digital Divide: Civic Engagement, Information Poverty, and the Internet Worldwide. New York: Cambridge University Press.

Organisation for Economic Co-operation and Development (OECD). (2003). Promise and Problems of E-Democracy: Challenges of Online Citizen Engagement. Paris: OECD Publications.

Organisation for Economic Co-operation and Development (OECD). (2001). Citizens as Partners: Information, Consultation and Public Participation in Policy-Making. Paris: OECD Publications.

O'Toole, K. (2009). Australia local government and e-governance: From administration to participation? In M. Khosrow-Pour (Ed.), E-Government Diffusion, Policy, and Impact: Advanced Issues and Practices (pp. 174-184). Hershey, Pennsylvania: IGI Global.

Seifert, J. W. (2006). E-government in the United States. In P. Hernon, R. Culleen \& H. C. Relyea (Eds.) Comparative Perspectives on E-Government: Serving Today and Building for Tomorrow (pp. 25-54). Lanham, Maryland: Scarecrow Press, Inc.

Sennett, R. (1977). The Fall of Public Man. New York: Alfred A. Knopf. 
Shackleton, P. (2010). Engaging citizens through local e-government: An Australian experience. In C. G. Reddick (Ed.), Citizens and E-Government: Evaluating Policy and Management (pp. 418-434). Hershey, Pennsylvania: IGI Global.

Smith, R. (2002). Modern citizenship. In E. Isin \& B. Turner (Eds.), Handbook of Citizenship Studies (pp. 105-116). London: Sage.

Statistics Iceland. (2012). Access to Computers and the Internet in Households 2002-2012. Retrieved February 2, 2013, from http://www.statice.is/Statistics/Tourism,-transport-and-informati/Information-technology

Stjórnlagarád. (2011). The Constitutional Council - General Information. Retrieved January 29, 2013, from http://stjornlagarad.is/english/

Tambini, D. (1999). New media and democracy: The civic networking movement. New Media \& Society, 1(3), 305-329.

Thompson, J. B. (2005). The new visibility. Theory, Culture \& Society, 22(6), 31-51.

Tolbert, C. J., \& Mossberger, K. (2006). The effects of e-government on trust and confidence in government. Public Administration Review, 66(3), 354-369.

United Nations. (2012). E-Government Survey 2012: E-Government for the People. New York: Department of Economic and Social Affairs, United Nations.

United Nations. (2010). E-Government Survey 2010: Leveraging E-Government at a Time of Financial and Economic Crisis. New York: Department of Economic and Social Affairs, United Nations.

Verdegem, P., \& Hauttekeete, L. (2010). A user-centric approach in e-government policies: The path to effectiveness? In. C. G. Reddick (Ed.), Citizens and E-Government: Evaluating Policy and Management (pp. 20-36). Hershey, Pennsylvania: IGI Global.

West, D. M. (2005). Digital Government: Technology and Public Sector Performance. Princeton, New Jersey: Princeton University Press.

Williamson, A. (2011). Disruption and empowerment: Embedding citizens at the heart of democracy. eJournal of eDemocracy and Open Government, 3(1), 22-32.

Wong, W., \& Welch, E. (2004). Does e-government promote accountability? A comparative analysis of website openness and government accountability. Governance: An International Journal of Policy, Administration, and Institutions, 17(2), 275-297.

\section{About the Authors}

Julie Freeman

Julie Freeman is a Postdoctoral Research Fellow in the News \& Media Research Centre at the University of Canberra, Australia. Julie received her PhD in Communications from Monash University in 2011. Her research interests include egovernment, local government, ICT-enabled citizen participation and engagement, digital democracy, and the policy contexts of digital government.

\section{Sharna Quirke}

Sharna Quirke is a consultant in public sector transformation and performance measurement. She has worked with governments worldwide on IT led transformation projects with a special focus on digital inclusion and the use of technology to deliver improved public services. She also advises public institutions and charities on the benefits of open source data to help measure social outcomes and improve operational business efficiencies. 